\title{
Pseudidiomarina aestuarii sp. nov., a marine bacterium isolated from shallow coastal seawater
}

Correspondence

Chi Nam Seong scnu@scnu.ac.kr
A study of Alteromonas-like bacteria by Ivanova et al. (2004) resulted in the proposal of the family Idiomarinaceae, on the basis of phylogeny and signature nucleotide positions in the $16 S$ rRNA gene. Members of the family Idiomarinaceae are unique among Alteromonas-like bacteria in possessing a high content of iso-branched fatty acids (Ivanova et al., 2004). The family Idiomarinaceae comprises two recognized genera: Idiomarina (Ivanova et al., 2000) as the type genus and Pseudidiomarina (Jean et al., 2006). Several species of the genus Pseudidiomarina are non-motile, while all species of the genus Idiomarina are motile by means of flagella.

At the time of writing, the genus Pseudidiomarina comprises eight species, with Pseudidiomarina taiwanensis as the type species (Jean et al., 2006, 2009; Hu \& Li, 2007; Wu et al., 2009). Members of the genus Pseudidiomarina have been isolated from saline habitats with a wide range of salinities such as coastal and oceanic waters, seashore sands, coastal sediment and solar salterns (Jean et al., 2006, 2009; Kwon et al., 2006; Yoon et al., 2007; $\mathrm{Hu} \& \mathrm{Li}, 2007 ; \mathrm{Wu}$ et al., 2009). During a survey of the diversity of heterotrophic marine bacteria, a bacterial strain, $\mathrm{KYW} 314^{\mathrm{T}}$, was recovered from seawater samples collected from the shallow coastal region of Gwangyang Bay in the south of the Republic of Korea $\left(34^{\circ} 51^{\prime} \mathrm{N} 128^{\circ} 47^{\prime} \mathrm{E}\right)$ in July 2008.

The GenBank/EMBL/DDBJ accession number for the 16S rRNA gene sequence of strain $\mathrm{KYW} 314^{\top}$ is FJ768737.

Biolog GN2 MicroPlate results for strain $\mathrm{KYW} 314^{\top}$ are available as supplementary material with the online version of this paper.
Strain KYW314 ${ }^{\mathrm{T}}$ was isolated from seawater using the standard dilution-plating technique. Isolation was achieved using marine agar 2216 (MA; BD) (Yang et al., 2006) at $30{ }^{\circ} \mathrm{C}$ for 7 days. The isolate was routinely cultured on MA and maintained at $-80{ }^{\circ} \mathrm{C}$ as a suspension in marine broth (MB; BD) containing glycerol $(20 \%, w / v)$.

DNA preparation and PCR amplification and sequencing of the 16S rRNA gene were carried out as described by Chun \& Goodfellow (1995). Identification of phylogenetic neighbours and calculation of pairwise $16 \mathrm{~S}$ rRNA gene sequence similarities were achieved using the EzTaxon server (http:// www.eztaxon.org/; Chun et al., 2007). Related sequences and the novel sequence were aligned using CLUSTAL $\mathrm{x}$ (Thompson et al., 1997) and the alignment was refined using PHYDIT (Chun, 1995). The phylogenetic analysis was performed by using PHYLIP (Felsenstein, 1993) and PAUP* version 4.0 (Swofford, 1998). Phylogenetic trees were inferred using the Fitch-Margoliash (Fitch \& Margoliash, 1967), maximum-likelihood (Felsenstein, 1993), maximum-parsimony (Fitch, 1971) and neighbour-joining (Saitou \& Nei, 1987) algorithms. Distance matrices for the neighbour-joining and Fitch-Margoliash methods were generated according to the model of Jukes \& Cantor (1969). The robustness of the topologies from each method was evaluated by bootstrap analyses (Felsenstein, 1985) with 1000 resamplings.

A preliminary sequence comparison with the newly determined 16S rRNA gene sequence from strain KYW $314^{\mathrm{T}}$ and sequences obtained from GenBank indicated that strain 
KYW $314^{\mathrm{T}}$ was closely related to the genus Pseudidiomarina. The 16S rRNA gene sequence from strain KYW $314^{\mathrm{T}}$ was then aligned manually with those from representatives of the genus Pseudidiomarina. Strain KYW314 ${ }^{\mathrm{T}}$ had a nucleotide T at position 143, whereas members of the genus Pseudidiomarina have a signature nucleotide A at this position (Jean et al., 2006). Strain KYW $314^{\mathrm{T}}$ showed the highest $16 \mathrm{~S}$ rRNA gene sequence similarity to Pseudidiomarina salinarum ISL-52 ${ }^{\mathrm{T}}$ $(97.3 \%)$, P. donghaiensis $908033^{\mathrm{T}}(96.7 \%)$ and other members of the genus Pseudidiomarina (96.6-95.4\%). In the neighbour-joining tree, strain KYW314 ${ }^{\mathrm{T}}$ formed a distinct branch with the clade comprising $P$. taiwanensis $\mathrm{PIT1}^{\mathrm{T}}$ and Pseudidiomarina sediminum $\mathrm{c} 21^{\mathrm{T}}$ and the same topology was seen in trees generated with the Fitch-Margoliash, maximumparsimony and maximum-likelihood algorithms (Fig. 1).

The taxonomic relationships of strain KYW $314^{\mathrm{T}}$ with $P$. salinarum KCTC $12971^{\mathrm{T}}$ and $P$. taiwanensis $\mathrm{PIT1}^{\mathrm{T}}$ were further examined using DNA-DNA hybridization. Genomic relatedness was determined with a membrane-filter technique (Seldin \& Dubnau, 1985) using a DIG High Prime DNA Labeling and Detection starter kit II (Roche) in duplicated reciprocal hybridization experiments. The DNA-DNA relatedness of strain $\mathrm{KYW} 314^{\mathrm{T}}$ to $P$. salinarum KCTC $12971^{\mathrm{T}}$ and $P$. taiwanensis $\mathrm{PIT1}^{\mathrm{T}}$ was 44.7 and $29.2 \%$, respectively. It was clear from the $16 \mathrm{~S}$ rRNA gene sequence analysis and the DNA-DNA hybridization data that strain KYW314 ${ }^{\mathrm{T}}$ represents a novel species in the genus Pseudidiomarina (Wayne et al., 1987).

Physiological tests with strain KYW $314^{\mathrm{T}}$ and its four closest phylogenetic neighbours were carried out under the same

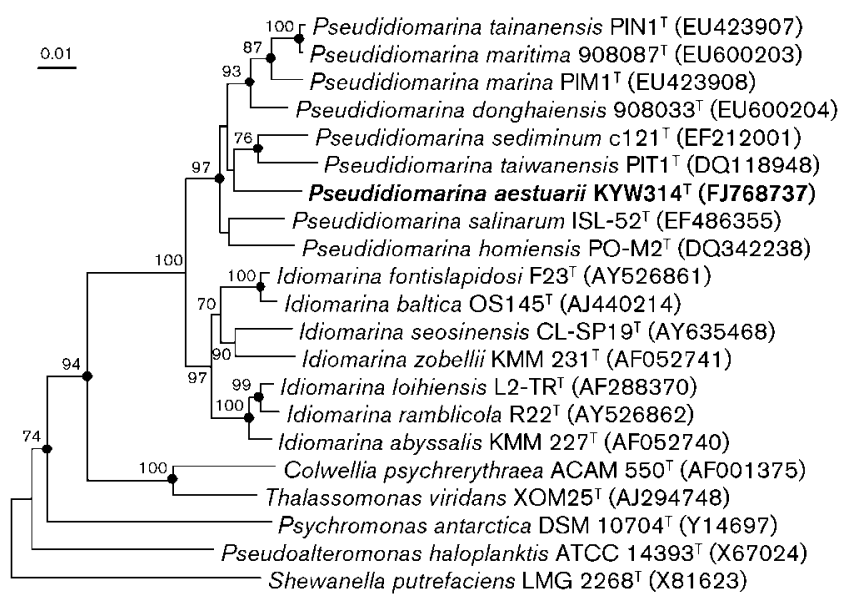

Fig. 1. Neighbour-joining phylogenetic tree based on almostcomplete 16S rRNA gene sequences showing the relationships between strain KYW314 ${ }^{\top}$, members of the genus Pseudidiomarina and representatives of related taxa. Bootstrap values $(>50 \%)$ based on 1000 resamplings are shown at branch nodes. Solid circles indicate that the corresponding nodes were also recovered in trees generated with the Fitch-Margoliash, maximum-parsimony and maximum-likelihood algorithms. Bar, 0.01 substitutions per nucleotide position. conditions using cells grown at $30{ }^{\circ} \mathrm{C}$ on $\mathrm{MA}$ for 2 days or in $\mathrm{MB}$ to exponential phase. Growth on various standard bacteriological media was tested by using nutrient agar (NA), tryptic soy agar (TSA), R2A agar (all from BD) and glucoseyeast extract agar. Motility was determined by observing cells grown in wet mounts by phase-contrast microscopy (TMSF; Nikon). Cell morphology after $30{ }^{\circ} \mathrm{C}$ for 2 days in $\mathrm{MB}$ was observed by phase-contrast and scanning electron microscopy (S-4800; Hitachi). For scanning electron microscopy, cells were soaked in $0.1 \mathrm{M}$ sodium phosphate buffer ( $\mathrm{pH}$ 7.4) for several hours, fixed in $0.5 \%$ glutaraldehyde and $0.5 \%$ paraformaldehyde in $0.1 \mathrm{M}$ sodium phosphate buffer (pH 7.4) and dehydrated through an ethanol/isoamyl alcohol series. The sample was subsequently critical-point dried with an SPI dry apparatus (JSM 5310; SPI Supplies) and osmium coater (Hollow Cathode Plasma CVD; Vacuum Device). Gram staining was performed using the method described by Smibert \& Krieg (1994). The requirement for $\mathrm{NaCl}(0.5 \%$ and $1-17 \%$, in increments of $1 \%$; Sigma) and sea salts $(0-10 \%$, in increments of $1 \%$; Sigma) for growth were tested using synthetic ZoBell liquid and agar medium (ZoBell, 1941) for up to 7 days. Growth at $\mathrm{pH} 3-11$, in increments of $1 \mathrm{pH}$ unit, was determined in ZoBell medium supplemented with $4 \%(\mathrm{w} / \mathrm{v})$ sea salts and the $\mathrm{pH}$ was adjusted by the addition of $\mathrm{HCl}$ and $\mathrm{NaOH}$. Growth at 4,10 , $13,15,20,25,30,37,40,42,45$ and $50{ }^{\circ} \mathrm{C}$ and growth in an anaerobic chamber $\left(\mathrm{CO}_{2} / \mathrm{H}_{2} / \mathrm{N}_{2}, 10: 10: 80\right.$; Sheldon Manufacturing) were checked on MA after incubation for up to 1 week. Catalase and oxidase activities were determined using 3\%(v/v) hydrogen peroxide and Kovács' reagent (Kovács, 1956), respectively. Acid production from Dglucose and maltose was tested on modified marine oxidation-fermentation (ZOF) medium (Lemos et al., $1985)$ supplemented with $0.5 \%(\mathrm{w} / \mathrm{v})$ carbohydrate. Nitrate reduction was tested on $\mathrm{MB}$ containing $0.2 \% \quad \mathrm{KNO}_{3}$ (Skerman, 1967). $\mathrm{H}_{2} \mathrm{~S}$ production was determined on Kligler iron agar (BD) supplemented with $4 \%(\mathrm{w} / \mathrm{v})$ sea salts. Hydrolysis of CM-cellulose $(1 \%, \mathrm{w} / \mathrm{v})$, casein $(2 \%$ skimmed milk, w/v), egg yolk ( $10 \%$, w/v), starch $(0.2 \%$, w/v) and Tweens 20 and $80(1 \%, w / v)$ was tested as described by Smibert \& Krieg (1994) using MA as the basal medium. Hydrolysis of L-tyrosine $(0.5 \%$, w/v) and xylan $(1 \%$, w/v) was tested as described by Barrow \& Feltham (1993) using $\mathrm{MA}$ as the basal medium. DNase activity was determined with DNase test agar (BD) supplemented with $4 \%(\mathrm{w} / \mathrm{v})$ sea salts. Carbon source utilization and enzymic activities were performed using the GN2 MicroPlate (Biolog) and API ZYM (bioMérieux) kits, respectively, according to the manufacturers' instructions except that bacterial strains were suspended in distilled water supplemented with $4 \%$ $(\mathrm{w} / \mathrm{v})$ sea salts. Antibiotic resistance was determined with the disc diffusion method using commercial antibioticimpregnated discs (BBL Becton Dickinson). After 5 days of incubation at $30{ }^{\circ} \mathrm{C}$ on $\mathrm{MA}$, the results were interpreted according to the guidelines set forth by CLSI (2003).

Strain KYW $314^{\mathrm{T}}$ grew well on MA and weakly on R2A, TSA and NA, but did not grow on glucose-yeast extract 
agar. There were several phenotypic characters that separated strain KYW $314^{\mathrm{T}}$ from phylogenetically related species, e.g. strain $\mathrm{KYW} 314^{\mathrm{T}}$ was positive for casein hydrolysis and negative for esterase (C4), esterase lipase (C8) and naphthol-AS-BI-phosphohydrolase. The detailed results of the physiological and biochemical analyses are given in Table 1, Supplementary Table S1 (available in IJSEM Online) and the species description.

For the analyses of fatty acid and $\mathrm{G}+\mathrm{C}$ contents, cells were grown on MA at $30{ }^{\circ} \mathrm{C}$ for 2 days. Fatty acids of strain KYW $314^{\mathrm{T}}$ and reference strains were prepared and analysed as methyl esters by GLC according to the instructions of the Sherlock Microbial Identification System (MIDI). For the determination of $\mathrm{G}+\mathrm{C}$ content, DNA samples were prepared in duplicate and analysed by the thermal denaturation method of Marmur \& Doty (1962).

The fatty acid profile of strain KYW $314^{\mathrm{T}}$ is given in Table 2. The proportions of the predominant fatty acids of strain KYW $314^{\mathrm{T}}$ were in the range of those for strains in the genus Pseudidiomarina, although the proportions of some straightchain saturated fatty acids in strain KYW $314^{\mathrm{T}}$ were slightly higher. The DNA G $+\mathrm{C}$ content of strain $\mathrm{KYW} 314^{\mathrm{T}}$ was
$56.4 \pm 0.4 \mathrm{~mol} \%$, which was slightly higher than those reported so far for the genus Pseudidiomarina.

The phylogenetic, genomic, chemotaxonomic and phenotypic data clearly indicate that strain KYW $314^{\mathrm{T}}$ represents a novel species within the genus Pseudidiomarina, for which the name Pseudidiomarina aestuarii sp. nov. is proposed.

\section{Description of Pseudidiomarina aestuarii sp. nov.}

Pseudidiomarina aestuarii (a.es.tu.ar'i.i. L. gen. n. aestuarii of a tract overflowed at high tide, a salt marsh, a bay, referring to the isolation of the type strain from shallow coastal seawater).

Cells are aerobic, non-motile rods, approximately $0.3 \mu \mathrm{m}$ wide and $0.7-1.4 \mu \mathrm{m}$ long. Colonies on MA medium are circular, convex, smooth, opaque and non-pigmented with entire margins and approximately $1.0-2.0 \mathrm{~mm}$ in diameter after 3 days at $30{ }^{\circ} \mathrm{C}(\mathrm{pH} 7)$. Growth occurs with $1-10 \%$ (w/v) $\mathrm{NaCl}$ (optimum $3 \%$ ) and $2-10 \%$ sea salts (optimum $4-5 \%)$. Growth occurs at $10-37{ }^{\circ} \mathrm{C}$ (optimum $30^{\circ} \mathrm{C}$ ) and at $\mathrm{pH}$ 5-10 (optimum pH 7). Positive for oxidase, catalase and production of acetoin. Negative for nitrate reduction, citrate utilization, production of $\mathrm{H}_{2} \mathrm{~S}$ and indole and

Table 1. Characteristics that serve to differentiate strain $\mathrm{KYW} 314^{\top}$ from the type strains of related Pseudidiomarina species

Strains: 1 , KYW314 31 ; P. homiensis KACC $11514^{\mathrm{T}}$ (data in parentheses taken from Kwon et al., 2006); 3, P. taiwanensis BCRC $17465^{\mathrm{T}}$ (Jean et al., 2006); 4, P. sediminum LMG $24046^{\mathrm{T}}$ ( $\mathrm{Hu} \& \mathrm{Li}, 2007$ ); 5, P. salinarum CCUG 54359 ${ }^{\mathrm{T}}$ (Yoon et al., 2007). Data were obtained in this study unless indicated otherwise. All strains were non-fermentative, rod-shaped and positive for hydrolysis of Tweens 20 and 80 and tyrosine and activity of oxidase and alkaline phosphatase. All strains were negative for hydrolysis of egg yolk and starch and activity of $N$-acetyl- $\beta$-glucosaminidase, $\alpha$ fucosidase, $\alpha$-galactosidase, $\beta$-galactosidase, $\beta$-glucosidase, $\alpha$-glucosidase, $\beta$-glucuronidase and $\alpha$-mannosidase.

\begin{tabular}{|c|c|c|c|c|c|}
\hline Characteristic & 1 & 2 & 3 & 4 & 5 \\
\hline Motility & - & + & - & - & + \\
\hline Catalase & + & + & + & - & + \\
\hline Range & $1-10$ & $1-15$ & $0.5-12(0.5-11)$ & $0.5-15$ & $1-15(1-14)$ \\
\hline Optimum & 3 & $2-5(3-5)$ & $2-4(1-4)$ & $1-8$ & $2-3$ \\
\hline Temperature range for growth $\left({ }^{\circ} \mathrm{C}\right)$ & $10-37$ & $4-45$ & $15-42$ & $10-42(13-42)$ & $4-42$ \\
\hline Nitrate reduction & - & + & + & - & + \\
\hline $\mathrm{H}_{2} \mathrm{~S}$ production & - & + & - & - & - \\
\hline \multicolumn{6}{|l|}{ Hydrolysis of: } \\
\hline Aesculin & + & + & + & - & - \\
\hline Casein & + & - & - & - & - \\
\hline DNA & + & + & - & + & + \\
\hline \multicolumn{6}{|l|}{ Enzyme activity (API ZYM) } \\
\hline Esterase (C4) & - & + & + & + & + \\
\hline Esterase lipase (C8) & - & + & + & + & + \\
\hline Leucine arylamidase & - & + & + & + & + \\
\hline Naphthol-AS-BI-phosphohydrolase & - & + & + & + & - \\
\hline Trypsin & - & + & + & - & - \\
\hline Valine arylamidase & - & $-(+)$ & $-(+)$ & - & $+(-)$ \\
\hline DNA G $+C$ content $(\mathrm{mol} \%)$ & 56.4 & $(45.1)$ & $(49.3)$ & $(50.0)$ & $(53.9)$ \\
\hline
\end{tabular}


Table 2. Cellular fatty acid contents of strain $\mathrm{KYW} 314^{\top}$ and the type strains of related Pseudidiomarina species

Strains: 1 , KYW $314^{\mathrm{T}} ; 2$, P. homiensis KACC $11514^{\mathrm{T}}$; 3, P. taiwanensis BCRC $17465^{\mathrm{T}} ; 4$, P. sediminum LMG $24046^{\mathrm{T}} ; 5$, P. salinarum CCUG $54359^{\mathrm{T}}$. Data were obtained in this study from cells grown on MA at $30{ }^{\circ} \mathrm{C}$ for 2 days. tr, Trace $(<1 \%)$; - , not detected.

\begin{tabular}{|c|c|c|c|c|c|}
\hline Fatty acid (\%) & 1 & 2 & 3 & 4 & 5 \\
\hline $\mathrm{C}_{12: 0}$ & $\operatorname{tr}$ & 1.4 & 1.0 & - & - \\
\hline $\mathrm{C}_{14: 0}$ & 1.1 & 1.3 & 1.4 & 1.5 & - \\
\hline $\mathrm{C}_{16: 0}$ & 11.1 & 8.9 & 7.5 & 9.5 & 5.3 \\
\hline $\mathrm{C}_{17: 0}$ & 1.2 & - & - & - & - \\
\hline $\mathrm{C}_{18: 0}$ & 7.0 & 3.4 & 4.2 & 2.9 & 4.0 \\
\hline iso- $\mathrm{C}_{11: 0}$ & 3.0 & 3.1 & 3.0 & 1.3 & 6.6 \\
\hline iso- $\mathrm{C}_{13: 0}$ & 1.1 & 1.6 & 5.4 & 2.0 & 1.8 \\
\hline iso- $\mathrm{C}_{15: 0}$ & 17.2 & 20.3 & 27.8 & 21.5 & 12.0 \\
\hline iso- $\mathrm{C}_{16: 0}$ & - & 9.0 & - & - & - \\
\hline iso- $\mathrm{C}_{17: 0}$ & 10.5 & 7.4 & 10.1 & 10.6 & 14.8 \\
\hline iso- $\mathrm{C}_{19: 0}$ & - & - & - & - & - \\
\hline $\mathrm{C}_{10: 0} 3-\mathrm{OH}$ & 2.6 & 2.3 & 1.3 & - & 1.2 \\
\hline $\mathrm{C}_{12: 0} 3-\mathrm{OH}$ & 2.5 & 2.5 & 1.5 & 2.2 & 1.7 \\
\hline $\mathrm{C}_{16: 0} 3-\mathrm{OH}$ & 1.6 & - & - & - & - \\
\hline iso- $\mathrm{C}_{11: 0} 3-\mathrm{OH}$ & 4.9 & - & 7.0 & 6.2 & 9.2 \\
\hline iso- $\mathrm{C}_{13: 0} 3-\mathrm{OH}$ & 4.3 & 5.4 & 4.7 & 4.6 & 6.8 \\
\hline iso- $\mathrm{C}_{17: 0} 3-\mathrm{OH}$ & 1.6 & - & - & - & - \\
\hline iso- $\mathrm{C}_{15: 1} \mathrm{~F}$ & 1.4 & 2.2 & 5.6 & 3.0 & 3.6 \\
\hline $\mathrm{C}_{17: 1} \omega 8 c$ & $\operatorname{tr}$ & - & - & 1.2 & - \\
\hline iso- $\mathrm{C}_{17: 1} \omega 9 c$ & 7.6 & 11.5 & 7.6 & 12.2 & 21.1 \\
\hline $\mathrm{C}_{18: 1} \omega 7 c$ & 10.0 & 8.8 & 4.8 & 10.1 & 7.1 \\
\hline $\mathrm{C}_{18: 1} \omega 9 c$ & 1.2 & 2.1 & - & 1.7 & - \\
\hline Summed feature $3^{*}$ & 7.5 & 9.9 & 7.3 & 8.0 & 4.8 \\
\hline
\end{tabular}

${ }^{*}$ Summed features represent groups of two or three fatty acids that cannot be separated by the Microbial Identification System. Summed feature 3 consists of $\mathrm{C}_{16: 1} \omega 7 c$ and/or iso- $\mathrm{C}_{15: 0} 2-\mathrm{OH}$.

activities of arginine dihydrolase, lysine decarboxylase, ornithine decarboxylase, tryptophan deaminase and urease. Hydrolyses casein, DNA, aesculin, Tweens 20 and 80 and tyrosine, but not CM-cellulose, egg yolk, starch or xylan. With API ZYM, alkaline phosphatase and $\alpha$-chymotrypsin are positive; other results are negative. With GN2 MicroPlates, weakly utilizes acetic acid, L-alaninamide, citric acid, i-erythritol, D-galactose, gentiobiose, $\alpha$-D-glucose, $\gamma$ hydroxybutyric acid, myo-inositol, lactose, D-mannose, methyl $\beta$-D-glucoside, propionic acid, L-pyroglutamic acid, L-rhamnose, D-sorbitol, thymidine and Tween 80 ; other substrates are not utilized. Cells are sensitive to ( $\mu \mathrm{g}$ per disc unless otherwise indicated): ampicillin (10), chloramphenicol (30), erythromycin (15), nalidixic acid (30), polymyxin B (300 IU) and vancomycin (30), but resistant to amikacin (30), gentamicin (10), kanamycin (30), penicillin (10 IU), streptomycin (10) and tetracycline (30). Major fatty acids $\left(>5 \%\right.$ of total fatty acid) are iso- $\mathrm{C}_{15: 0}, \mathrm{C}_{16: 0}$, iso- $\mathrm{C}_{17: 0}$, $\mathrm{C}_{18: 1} \omega 7 c$, iso- $\mathrm{C}_{17: 1} \omega 9 c$ and summed feature $3\left(\mathrm{C}_{16: 1} \omega 7 c\right.$ and/or iso- $\left.\mathrm{C}_{15: 0} 2-\mathrm{OH}\right)$. The DNA G $+\mathrm{C}$ content of the type strain is $56.4 \mathrm{~mol} \%$.
The type strain is $\mathrm{KYW} 314^{\mathrm{T}}\left(=\mathrm{KCTC} 22740^{\mathrm{T}}=\mathrm{JCM}\right.$ $\left.16344^{\mathrm{T}}\right)$, isolated from seawater collected from the South Sea, Republic of Korea.

\section{Acknowledgements}

This research was supported by the 21C Frontier Microbial Genomics and Applications Center Program, Ministry of Education, Science \& Technology, Republic of Korea.

\section{References}

Barrow, G. I. \& Feltham, R. K. A. (1993). Cowan and Steel's Manual for the Identification of Medical Bacteria, 3rd edn. Cambridge: Cambridge University Press.

Chun, J. (1995). Computer-assisted classification and identification of actinomycetes. PhD thesis, University of Newcastle, Newcastle, UK.

Chun, J. \& Goodfellow, M. (1995). A phylogenetic analysis of the genus Nocardia with 16S rRNA gene sequences. Int J Syst Bacteriol 45, 240-245.

Chun, J., Bae, K. S., Moon, E. Y., Jung, S. O., Lee, H. K. \& Kim, S. J. (2000). Nocardiopsis kunsanensis sp. nov., a moderately halophilic actinomycete isolated from a saltern. Int J Syst Evol Microbiol 50, 1909-1913.

Chun, J., Lee, J.-H., Jung, Y., Kim, M., Kim, S., Kim, B. K. \& Lim, Y. W. (2007). EzTaxon: a web-based tool for the identification of prokaryotes based on $16 \mathrm{~S}$ ribosomal RNA gene sequences. Int J Syst Evol Microbiol 57, 2259-2261.

CLSI (2003). Performance standards for antimicrobial disk susceptibility tests, 8th edn. Approved Standard M2-A8. Wayne, PA: Clinical and Laboratory Standards Institute.

Felsenstein, J. (1985). Confidence limits on phylogenies: an approach using the bootstrap. Evolution 39, 783-791.

Felsenstein, J. (1993). PHYLIP (phylogeny inference package), version 3.5c. Distributed by the author. Department of Genome Sciences, University of Washington, Seattle, USA.

Fitch, W. M. (1971). Toward defining the course of evolution: minimum change for a specific tree topology. Syst Zool 20, 406416.

Fitch, W. M. \& Margoliash, E. (1967). Construction of phylogenetic trees. Science 155, 279-284.

Hu, Z. Y. \& Li, Y. (2007). Pseudidiomarina sediminum sp. nov., a marine bacterium isolated from coastal sediments of Luoyuan Bay in China. Int J Syst Evol Microbiol 57, 2572-2577.

Ivanova, E. P., Romanenko, L. A., Chun, J., Matte, M. H., Matte, G. R., Mikhailov, V. V., Svetashev, V. I., Huq, A., Maugel, T. \& Colwell, R. R. (2000). Idiomarina gen. nov., comprising novel indigenous deep-sea bacteria from the Pacific Ocean, including descriptions of two species, Idiomarina abyssalis sp. nov. and Idiomarina zobellii sp. nov. Int J Syst Evol Microbiol 50, 901-907.

Ivanova, E. P., Flavier, S. \& Christen, R. (2004). Phylogenetic relationships among marine Alteromonas-like proteobacteria: emended description of the family Alteromonadaceae and proposal of Pseudoalteromonadaceae fam. nov., Colwelliaceae fam. nov., Shewanellaceae fam. nov., Moritellaceae fam. nov., Ferrimonadaceae fam. nov., Idiomarinaceae fam. nov. and Psychromonadaceae fam. nov. Int J Syst Evol Microbiol 54, 1773-1788.

Jean, W. D., Shieh, W. Y. \& Chiu, H.-H. (2006). Pseudidiomarina taiwanensis gen. nov., sp. nov., a marine bacterium isolated from shallow coastal water of An-Ping Harbour, Taiwan, and emended 
description of the family Idiomarinaceae. Int J Syst Evol Microbiol 56, 899-905.

Jean, W. D., Leu, T. Y., Lee, C.-Y., Chiu, T.-J., Lin, S. Y. \& Shieh, W. Y. (2009). Pseudidiomarina marina sp. nov. and Pseudidiomarina tainanensis sp. nov. and reclassification of Idiomarina homiensis and Idiomarina salinarum as Pseudidiomarina homiensis comb. nov. and Pseudidiomarina salinarum comb. nov., respectively. Int J Syst Evol Microbiol 59, 53-59.

Jukes, T. H. \& Cantor, C. R. (1969). Evolution of protein molecules. In Mammalian Protein Metabolism, vol. 3, pp. 21-132. Edited by $\mathrm{H}$. N. Munro. New York: Academic Press.

Kovács, N. (1956). Identification of Pseudomonas pyocyanea by the oxidase reaction. Nature 178, 703.

Kwon, S.-W., Kim, B.-Y., Weon, H.-Y., Baek, Y.-K., Koo, B.-S. \& Go, S.-J. (2006). Idiomarina homiensis sp. nov., isolated from seashore sand in Korea. Int J Syst Evol Microbiol 56, 2229-2233.

Lemos, M. L., Toranzo, A. E. \& Barja, J. L. (1985). Modified medium for the oxidation-fermentation test in the identification of marine bacteria. Appl Environ Microbiol 49, 1541-1543.

Marmur, J. \& Doty, P. (1962). Determination of the base composition of deoxyribonucleic acid from its thermal denaturation temperature. J Mol Biol 5, 109-118.

Saitou, N. \& Nei, M. (1987). The neighbor-joining method: a new method for reconstructing phylogenetic trees. Mol Biol Evol 4, 406425.

Seldin, L. \& Dubnau, D. (1985). Deoxyribonucleic acid homology among Bacillus polymyxa, Bacillus macerans, Bacillus azotofixans, and other nitrogen-fixing Bacillus strains. Int J Syst Bacteriol 35, 151154.
Skerman, V. B. D. (1967). A Guide to the Identification of the Genera of Bacteria, 2nd edn. Baltimore: Williams \& Wilkins.

Smibert, R. M. \& Krieg, N. R. (1994). Phenotypic characterization. In Methods for General and Molecular Bacteriology, pp. 607-654. Edited by P. Gerhardt, R. G. E. Murray, W. A. Wood \& N. R. Krieg. Washington, DC: American Society for Microbiology.

Swofford, D. L. (1998). PAUP: phylogenetic analysis using parsimony, version 4. Sunderland, MA: Sinauer Associates.

Thompson, J. D., Gibson, T. J., Plewniak, F., Jeanmougin, F. \& Higgins, D. G. (1997). The CLUSTAL_X windows interface: flexible strategies for multiple sequence alignment aided by quality analysis tools. Nucleic Acids Res 25, 4876-4882.

Wayne, L. G., Brenner, D. J., Colwell, R. R., Grimont, P. A. D., Kandler, O., Krichevsky, M. I., Moore, L. H., Moore, W. E. C., Murray, R. G. E. \& other authors (1987). International Committee on Systematic Bacteriology. Report of the ad hoc committee on reconciliation of approaches to bacterial systematics. Int J Syst Bacteriol 37, 463-464.

Wu, Y.-H., Shen, Y.-Q., Xu, X.-W., Wang, C.-S., Oren, A. \& Wu, M. (2009). Pseudidiomarina donghaiensis sp. nov. and Pseudidiomarina maritima sp. nov., isolated from the East China Sea. Int J Syst Evol Microbiol 59, 1321-1325.

Yang, S.-H., Kwon, K. K., Lee, H.-S. \& Kim, S.-J. (2006). Shewanella spongiae sp. nov., isolated from a marine sponge. Int J Syst Evol Microbiol 56, 2879-2882.

Yoon, J.-H., Jung, S.-Y., Jung, Y.-T. \& Oh, T.-K. (2007). Idiomarina salinarum sp. nov., isolated from a marine solar saltern in Korea. Int $J$ Syst Evol Microbiol 57, 2503-2506.

ZoBell, C. E. (1941). Studies on marine bacteria. I. The cultural requirements of heterotrophic aerobes. J Mar Res 4, 42-75. 